\title{
The post-2010 'Democratic Rule of Law' practice of the Hungarian Constitutional Court under a rule by law governance
}

\author{
NÓRA CHRONOWSKI ${ }^{1,2 *}$ [
}

\footnotetext{
${ }^{1}$ National University of Public Service Faculty of Law Enforcement, Budapest, Hungary

${ }^{2}$ Centre for Social Sciences Institute for Legal Studies Budapest, Budapest, Hungary
}

\section{ORIGINAL RESEARCH PAPER}

\begin{abstract}
The paper focuses on the democratic rule of law principle as it appeared in the practice of the Hungarian Constitutional Court under the 1989 Constitution and the 2012 Fundamental Law. The rule of law doctrine had a paramount role in the argumentation of the Court in the 1990s as a normative fact and a programme of the Hungarian state. Under the Fundamental Law introduced in 2012, however, it has been somewhat relegated to the background in case law. The study first recalls the main achievements and characteristics of the democratic rule of law state interpretations of the Constitutional Court and then focuses on developments since the introduction of the Fundamental Law. On the one hand, it outlines the constitutional and institutional capacity of the court regarding the protection of the rule of law principle. On the other hand, it reveals the characteristics of the post-FL interpretation through case studies in the field of legal certainty and judicial independence, both of which were representative elements of the pre-2010 constitutional practice from the point of view of the democratic rule of law state doctrine.
\end{abstract}

\section{KEYWORDS}

rule of law, democracy, Hungarian Constitutional Court, legal certainty, judicial independence

\footnotetext{
*Corresponding author. E-mail: chronowski.nora@tk.hu

This study forms part of the research project № 128796 funded by the National Research Development and Innovation Office, investigating the normative content of the principle of democracy from the perspective of European Union and constitutional law.
} 


\section{INTRODUCTION}

Under the new Fundamental Law of Hungary, which, like the 1989 Constitution, places the rule of law at the centre of the constitutional order, ${ }^{1}$ the constraints which follow from the rule of law have been habitually overridden or ignored by the government acting in parliament. ${ }^{2}$

The government's reaction to the Constitutional Court's attempts to continue the legacy of pre-2010 constitutionalism has included delimiting the powers of the Court and overruling its decisions in formal amendments of the constitutional text.

The Hungarian constitutional transformation since 2010 has attracted widespread attention throughout Europe. There have been various explanations surrounding the creation of the new constitutional identity, including criticism ${ }^{3}$ or concerns, ${ }^{4}$ and even welcoming comments and self-justification. ${ }^{5}$ Since the entry into force of the Fundamental Law 'several significant systemic developments indicate that in the new constitutional order the ability of the government to rule by law enjoys priority over the idea that for a government to be constitutional it must be tempered by the democratic rule of law. ${ }^{6}$

The new Fundamental Law seemingly accorded a position in Hungarian constitutionalism to the rule of law similar to that in the 1989 Constitution. Its Article B) recognised the rule of law and democracy as the foundational principles of the state. Article C) contains the now selfstanding principle of the separation of powers, which principle continues to be expressed in the detailed constitutional provisions on the organisation and the functioning of the state. Beyond the constitutional text, there are, however, several systemic developments which soon raised doubts as to the above-mentioned commitment of the new constitutional order to sustaining and building upon the legacy of post-1989 Hungarian constitutionalism. These developments include the instability of the constitution which followed from its frequent, politically-driven modifications, the imposition of serious limitations on the constitutional review exercised by the Constitutional Court, and the open struggle between the Constitutional Court and the government acting in parliament for the supreme constitutional authority in the country (2010-2013).

The Constitutional Court was not able - and later was not willing - to withstand the pressure, and the demise of pre-2010 rule of law standards is visible. In this paper, I analyse the decline of the democratic rule of law standards, and the reasons it has occurred. First, the pre2010 legacy will be recalled (Section 2), then the background of the erosion, i.e. the constitutional and institutional incapacitation of the Court (court packing), will be considered (Section 3). Finally, the post-2010 case law will be presented with special regard to legislation and legal certainty (Section 4), and judicial independence (Section 5).

\footnotetext{
${ }^{1}$ Article B) para. (1) of the Hungarian Fundamental Law (as in force in November 2018): 'Hungary shall be an independent, democratic rule-of-law State.'

${ }^{2}$ Chronowski (2018) 11.

${ }^{3}$ See Kovács and Tóth (2011) 183-203, Tóth (2012), Pap (2018), Halmai (2018a), Halmai (2018b), Halmai (2018c), Kelemen (2017), Mészáros (2021).

${ }^{4}$ See Küpper (2012), Jakab and Sonnevend (2013), Vincze (2014b), Szente and others (2015).

${ }^{5}$ See Csink and others (2012), Varga and others (2015), Trócsányi (2016).

${ }^{6}$ As we stated it earlier in Chronowski and Varju (2017) 149-68.
} 


\section{THE DEMOCRATIC RULE OF LAW STATE UNDER THE CONSTITUTION}

The rule of law enjoyed a paramount position among the norms which constituted the constitutional order of post-1989 Hungary. It was modelled almost exclusively on the German Rechtsstaat concept. ${ }^{7}$ The influence of the Rechtsstaat principle also meant that in Hungary the written constitution enjoys the highest rank in the hierarchy of legal norms, superseding other pieces of legislation, a primacy which is manifested primarily through the process of constitutional review exercised by the Constitutional Court. The jurisprudence developed by the Constitutional Court in a long chain of constitutional review cases emphasized primarily the formal dimensions of the rule of law, ${ }^{8}$ especially the principle of legal certainty, and left the substantive aspects of the principle somewhat underdeveloped. ${ }^{9}$

The prominence of the rule of law among the principles of the constitution, which was matched by the human dignity principle, and the emphasis on its formal dimensions were thought to provide an essential guarantee for the successful completion of the post-1989 transition process. ${ }^{10}$ The position held on the rule of law by the Constitutional Court, a key actor in the process of political and legal transition, was simple, but effective: 'the rule of law cannot be achieved against the rule of law'. ${ }^{11}$ This meant, first and foremost, that the Court systematically enforced the principle of legal certainty and applied the rule of law, which it aimed to interpret and develop as a neutral concept, ${ }^{12}$ as the fundamental benchmark of its constitutional control powers. ${ }^{13}$ It was interpreted as having a normative content independent of concrete constitutional provisions the violation of which could give rise to protection before the Constitutional Court. The rule of law was also available to support as their conceptual basis more specific constitutional norms, and it provided a philosophical umbrella for the entire constitutional order, the individual norms of which were in turn available to give effect in individual instances to the rule of law as a general principle.

In the jurisprudence of the Constitutional Court under the 1989 Constitution, ${ }^{14}$ the rule of law emerged as a self-standing normative principle, and it was used to provide the basis of other, more specific constitutional norms, such as legal certainty and the separation of powers.

\footnotetext{
${ }^{7}$ As László Sólyom, the first president of the Constitutional Court outlined 'Even the traditional difference between the formal and the substantial concepts of the Rechtsstaat (...) was revived and had to be reinterpreted. (...) The Court made both the politicians and the population conscious of the secure protection of constitutional rights (...) and aware of one of the most important characteristics of the rule of law: political intentions can only be implemented lawfully and within the framework of the Constitution - not vice versa, as before, when the law was conceived as merely a political tool. (...) The Court, moreover, developed a moral explanation of its position. It introduced the paradoxical phrase "revolution under the rule of law".' Sólyom (2000) 38.

${ }^{8}$ The formal rule of law requirements include legal certainty, procedural guarantees, such as the protection against retroactive laws, and the separation of powers. See to this Krygier (2012) 237-40.

${ }^{9}$ Györfi and Jakab (2009) 174.

${ }^{10}$ Sólyom (2015) 6-7.

${ }^{11}$ HCC Decision 11/1992. (III. 5.) AB.

${ }^{12}$ Tóth (2009) 147.

${ }^{13}$ For example, the Constitutional Court never paid much attention to the concept of democracy and to its relevance in constitutional interpretation; see the minority opinion of Judge Kiss in HCC Decision 39/1999. (XII. 21.) AB.

${ }^{14}$ Act XX of 1949 on the Constitution of the Republic of Hungary as revised in 1989-90, in force until 31 December 2011.
} 
The main directions of the interpretation of the rule of law principle were the limits of the exercise of public power and the division of powers, the legality of public administration, legislation and legal certainty. ${ }^{15}$ Regarding the exercise of public powers, the Court emphasized that it should be bound to legal norms, and must be predictable and limited; ${ }^{16}$ that the state should function transparently; ${ }^{17}$ and that there is a requirement of democratic legitimacy. ${ }^{18}$ The division and separation of powers principle did not appear in the 1989 Constitution expressly, thus the Court regarded it as part of the rule of law principle and protected it as the most important organisational and functional principle of the Hungarian state structure. ${ }^{19}$ The rule of law requirements of the legislation were the democratic legitimacy of legislative bodies, ${ }^{20}$ the prohibition of incorporating individual acts into legislative measures, ${ }^{21}$ and the preparation time required when a new legislative act comes into force. ${ }^{22}$ A well elaborated case law was related to the principle of legal certainty, the starting point of which is well-known: 'Legal certainty is an indispensable component of the rule of law. Legal certainty compels the State - and primarily the legislature - to ensure that the law on the whole, in its individual parts and in its specific legal rules, are clear and unambiguous and that their addressees find their operation ascertainable and predictable. Thus, legal certainty requires not merely the unambiguity of individual legal norms but also the predictability of the operation of individual legal institutions. It is for these reasons that procedural guarantees are fundamental for legal certainty. Only by following the formal rules of procedure may a valid legal rule be created, only by complying with the procedural norms do the legal institutions operate in a constitutional manner. ${ }^{23}$ This practice was accompanied by the doctrine of the clarity of legal norms, ${ }^{24}$ the predictable functioning of legal institutions, ${ }^{25}$ the prohibition of harmful (disadvantageous) legislative effect $^{26}$ and the protection of acquired rights. ${ }^{27}$ The legality of public administration meant in the Court's practice that administrative acts are bound by law, ${ }^{28}$ that there exists the right to good administration (fair administrative procedure), to respect for the fundamental rights of the clients, ${ }^{29}$ and to an impartial and politically neutral public administration. ${ }^{30}$

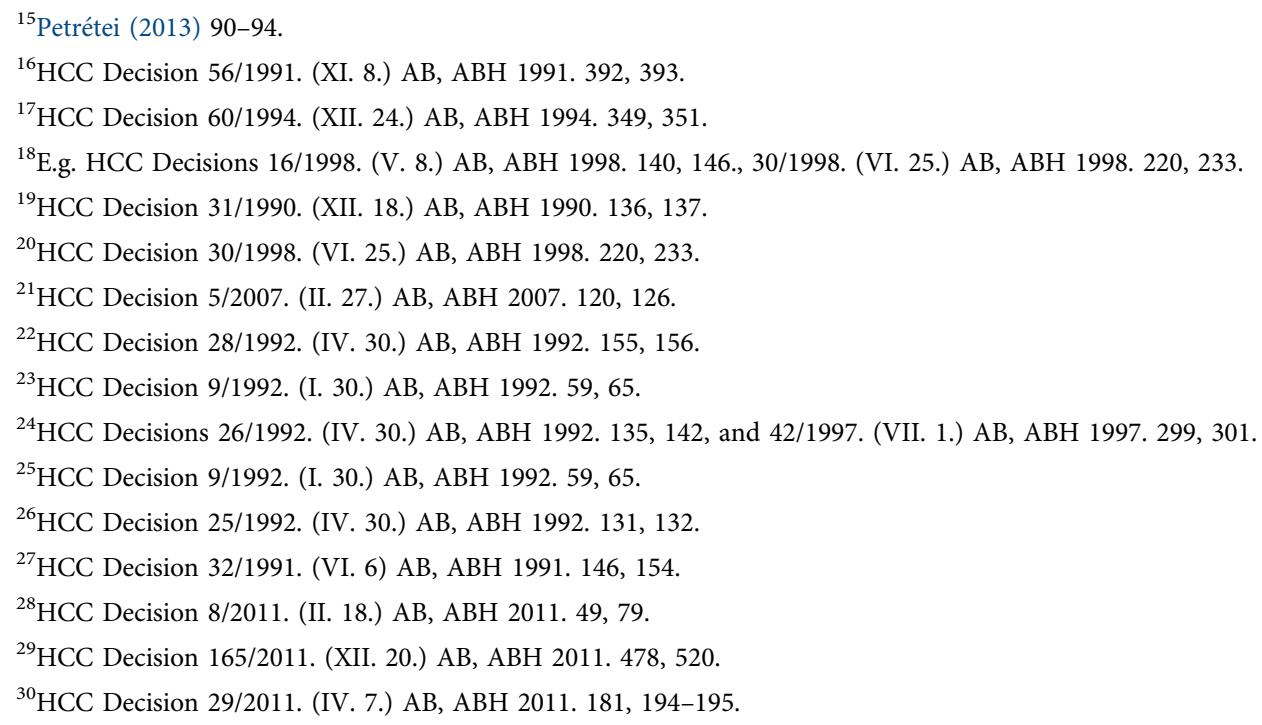




\section{CONSTITUTIONAL AND INSTITUTIONAL CAPACITY OF THE CONSTITUTIONAL COURT}

The new constitution, the Fundamental Law of Hungary (hereinafter FL), was promulgated on 25 April 2011 and came into force on 1 January 2012. Its drafting rose to prominence in Europe and was severely criticized both by domestic experts ${ }^{31}$ and the Venice Commission. After the 2010 parliamentary elections, political forces forming a parliamentary majority - possessing two-thirds of the seats - had expressed their intention to create a new constitution. In the course of 'replacing the old with new' the development of another constitutional regime and the writing of the FL came about in parallel with the devastation of the previous constitutional order with permanent amendments to the former Constitution. In the background of this policy the unequal fight between the Constitutional Court and the governing majority took place, which might be summarised by the question 'Who is the final arbiter in constitutional matters?' ${ }^{32}$ This struggle ended in the partial incapacitating of the Constitutional Court by weakening it as a counterbalance to the executive and legislative powers. ${ }^{33}$ Until the Fourth Amendment (2013) the Court made cautious efforts to strike down the efforts of the supermajority government acting in the parliament. ${ }^{34}$ Since then, and especially after the first failure (2016) of the Seventh Amendment - as the institutional and competence changes took effect - the Court has given a helping hand to the constitution maker, and is even ready to substitute the constituent will with the intentions of the government. ${ }^{35}$

After the 2010 parliamentary elections, parallel with the declaration of the creation of a brand-new constitution, the permanent amendments to the old Constitution also commenced. These amendments can be grouped into two types: 'normal' modifications and 'demolishing' amendments. The 'normal' modifications did not cause a systemic change in the structure of the Constitution; ${ }^{36}$ however, only the minority of the 2010-11 amendments belonged to this group.

The subject matters of the 'demolishing' amendments were as follows:

1. nomination of Constitutional Court judges, ${ }^{37}$

2. freedom of press - creating a constitutional basis for a new media legislation, ${ }^{38}$

3. the judiciary: allowing court clerks to act as judges in certain cases, ${ }^{39}$

\footnotetext{
${ }^{31}$ Vincze and Varju (2012) 437-53.

${ }^{32}$ Chronowski and Varju (2016) 281-82.

${ }^{33}$ Szente (2015) 192-96.

${ }^{34}$ Chronowski (2015) 223-40.

${ }^{35}$ Chronowski and Vincze (2017) 117-18.

${ }^{36}$ E.g. the position of deputy prime minister was introduced, or the status of the prosecutor general was reformed to increase its independence.

${ }^{37}$ Act of 5 July 2010 authorised the governing majority in the parliament to nominate judges unilaterally, without the consent of the opposition.

${ }^{38}$ Act $/ 2$ of 6 July 2010.

${ }^{39}$ Act $/ 2$ of 11 August 2010.
} 
4. the special tax on severance pay against bona fides (morals) in public service, ${ }^{40}$

5. limitations on the right to be elected for officials of the armed forces, ${ }^{41}$

6. the limitation of the Constitutional Court's competence regarding the review of acts concerning public finances, ${ }^{42}$

7. the special tax on severance pay - retroactive legislation going back five years, ${ }^{43}$

8. the basis for changing pension system in order to get rid of early retirement benefits, ${ }^{44}$

9. the nationalisation of local authority property, ${ }^{45}$

10. the judiciary: the president of the Kúria (Supreme Court) shall be elected until 31 December 2011,46

11. the president of the Constitutional Court shall be elected by the parliament instead of the court itself, and 15 instead of 11 judges shall be elected. ${ }^{47}$

A fairly clear line threatening the (constitutional) judiciary and undermining the rule of law can be observed in this group of amendments, while the supermajority strove to eliminate the constitutional impediments to economic governance and policymaking, as well. $^{48}$

The new Fundamental Law (FL) and a new Act on the Constitutional Court (ACC) ${ }^{49}$ brought further changes in the scope of constitutional review, and the protection of the constitution.

Regarding the mechanism for safeguarding the constitution, one of the weaknesses is that the FL - similarly to the former Constitution - can be amended relatively easily, only a two-thirds majority of all MPs is needed. The constitution amending process that started in 2010 and led to the constant amendments of the former Constitution based on ad hoc political interests, made it clear that more guarantees are necessary - e.g. unchangeable provisions (an eternity clause), referenda on certain amendments, the approval of two sequential parliaments - for a stable constitution. The overwhelming practice of amending the constitution is occurring with the FL as well, because the governing majority adopts modifications again and again with the purpose of punishing the Constitutional Court for unfavourable decisions, overruling the Court's judgements or preventing constitutional review.

\footnotetext{
${ }^{40}$ Act $/ 2$ of 11 August 2010.

${ }^{41}$ Act $/ 1$ of 11 August 2010 (it was not maintained in the FL).

${ }^{42}$ Act CXIX of 2010 (published on 19 November 2010, which was announced as a temporary limitation, but which has been maintained by the FL).

${ }^{43}$ Act CXIX of 2010 (published on 19 November 2010).

${ }^{44}$ Act LXI of 2011 (published on 14 June 2011).

${ }^{45}$ Act CXLVI of 2011 (published on 14 November 2011).

${ }^{46}$ Act CLIX of 2011 (published on 1 December 2011; with the intention to remove the acting president, András Baka; later the European Court of Human Rights stated that the Convention had been violated, see Baka v. Hungary, Judgement of 27 May 2014, no. 20261/12.). For details of the case, see Vincze (2015) 445-56.

${ }^{47}$ Act LXI of 2011 (published on 14 June 2011).

${ }^{48}$ Varju and Chronowski (2015) 298.

${ }^{49}$ Act CLI of 2011 on the Constitutional Court.
} 
The key institution in safeguarding the constitution is the Constitutional Court. In parliamentary governmental systems, if the government is supported by a wide parliamentary majority, constitutional jurisdiction counterbalancing the unity of action of parliament and government constitutes the guarantee of the separation of powers and the sovereignty of the law (constitution). The greater the unity of action between the parliament and government, the wider the competence needed for constitutional jurisdiction to maintain the balance. The FL and the new ACC brought changes in the scope of the constitutional review. The actio popularis (without personal interest) initiation of subsequent norm control was eliminated, and the constitutional complaint procedures were reformed: not only legislative acts (ACC §26) but also judicial decisions (ACC §27) can be challenged if they violate rights guaranteed by the FL and the petitioner is personally, directly and effectively concerned. Soon the constitutional complaint procedures came to the forefront of the Constitutional Court's proceedings, ${ }^{50}$ and the Constitutional Court's control activity shifted from the legislator to the ordinary courts.

In respect of the principle of rule of law, it is very harmful that the FL upholds for an indefinite time the restriction of the supervision and annulment rights of the Constitutional Court which was introduced in November 2010. ${ }^{51}$ More specifically, Article 37(4) of the Chapter on Public Finances of the FL lays down that with regard to ex post norm control and constitutional complaint procedures, the Constitutional Court is prevented from reviewing the content of, or annulling, acts on public finances, with the exception of four 'protected fundamental rights', as long as state debt exceeds half of the Gross Domestic Product. ${ }^{52}$ Thus, the power of annulment is curtailed by Article 37(4) of the FL, because it excludes the constitutional review and annulment of Acts relating to public finances from the content side, apart from four exceptions. This is not rectified even by the fact that Acts relating to this subject-matter may be annulled in cases in which the requirements of the legislative process have not been met (for formal reasons). Paradoxically, in this way the FL also excludes the protection by the Constitutional Court of its own provisions relating to public finances, because the violation of rules relating to public finances contained in the FL is most likely to occur by way of Acts relating to the state budget, taxes, customs duties etc., which are subject to ex post review by the Constitutional Court only from the perspective of the four protected fields of fundamental rights. The Transitional

\footnotetext{
${ }^{50}$ See also Table 1 below.

${ }^{51}$ By a constitutional amendment in November 2010, a serious limitation of the competences of the Constitutional Court was introduced. According to this amendment, the Constitutional Court may assess the constitutionality of Acts related to the state budget, central taxes, duties and contributions, custom duties and central conditions for local taxes exclusively as they relate to the rights to life and human dignity, the protection of personal data, the freedom of thought, conscience and religion or to rights related to Hungarian citizenship. Also, the Court may only annul these Acts in cases of violations of the above-mentioned rights. The restriction of the Constitutional Court's competences was the response of the alliance of the governing parties to a Court decision which annulled a law on a certain tax imposed with retroactive effect.

52، As long as state debt exceeds half of the Gross Domestic Product, the Constitutional Court may, within its competence set out in Article 24(2)b-e), only review the Acts on the State Budget and its implementation, the central tax type, duties, pension and healthcare contributions, customs and the central conditions for local taxes for conformity with the Fundamental Law or annul the preceding Acts due to a violation of the right to life and human dignity, the right to the protection of personal data, freedom of thought, conscience and religion, and with the rights related to Hungarian citizenship. The Constitutional Court shall have the unrestricted right to annul the related Acts for non-compliance with the Fundamental Law's procedural requirements for the drafting and publication of such legislation.'
} 
Provisions to the FL (hereinafter: TPFL) upheld and extended the effect of the disputed limitation on constitutional review, ${ }^{53}$ and the Fourth Amendment incorporated it into the FL. ${ }^{54}$

The restriction of the Constitutional Court's rights of review and annulment is not in conformity with the principles of European constitutional achievements, nor with the traditions of Hungarian constitutionalism and democratic political culture developed since 1989-90. It violates the constitutional principles of the rule of law, legal certainty and the separation of powers. Because of the restriction of the procedure of the Constitutional Court, numerous fundamental rights (especially, for example, the right to property, social rights, the freedom of enterprise, the right to a profession) become 'defenceless' ${ }^{55}$

The TPFL's purpose was to support the coming into force of the FL, and it was adopted in December 2011. However, the TPFL overruled several important statements made by the Constitutional Court, e.g. on the right to be heard by a lawful and impartial judge, ${ }^{56}$ and undermined some rules of the FL itself. ${ }^{57}$ According to the Commissioner for Fundamental Rights of Hungary, the TPFL 'severely harms the principle of the rule of law, which may cause problems of interpretation and may endanger the unity and operation of the legal system. The Ombudsman is concerned because the Transitional Provisions contain many rules which obviously do not have a transitional character. ${ }^{58}$ Thus the Ombudsman requested the Constitutional Court to examine whether the Transitional Provisions comply with the requirements of the rule of law laid down in the FL. Following the Ombudsman's initiative, the Parliament adopted the First Amendment to the FL, clarifying that the Transitional Provisions are part of the FL. By this amendment the governing majority intended to avoid the constitutional review of the TPFL, confirming its constitutional rank. ${ }^{59}$ Despite this, the Constitutional Court ruled on the Ombudsman's petition, declaring that all the provisions of the TPFL which lacked a transitory character were invalid. ${ }^{60}$ The Constitutional Court declared that the Hungarian Parliament had exceeded its legislative authority when it enacted

${ }^{53}$ Article 27 of the TPFL: 'Article 37(4) of the Fundamental Law shall remain in force for Acts that were promulgated when the state debt to the Gross Domestic Product ratio exceeded 50\% even if the ratio no longer exceeds $50 \%$.' This Article was also annulled by the Constitutional Court in its HCC Decision 45/2012. (XII. 29.) AB.

${ }^{54}$ See Art. 17 of the Fourth Amendment.

${ }^{55}$ See also Opinion № 621/2011 of the Venice Commission, points 91-101, 120-27.

${ }^{56}$ HCC Decision 166/2011 (XII. 20.) AB.

${ }^{57}$ On the TPFL and other cardinal acts read more at link 1.

${ }^{58}$ For the petition of the Ombudsman lodged in March, 2012 to the Constitutional Court concerning the TPFL, see link 2.

${ }^{59}$ In April 2012 the Government of Hungary presented a bill to the Parliament as the First Amendment of the FL of Hungary so as to clarify that the Transitional Provisions are a part of the FL. The First Amendment was adopted in June 2012. It added a new 5th point to the Closing Provisions of the FL: '5. The transitional provisions related to this Fundamental Law adopted according to point 3 (31 December 2011) are part of the Fundamental Law.' Other relevant points of the Closing Provisions: '2. Parliament shall adopt this Fundamental Law according to point a) of subsection (3) of Section 19 and subsection (3) of Section 24 of Act XX of 1949. 3. The transitional provisions related to this Fundamental Act shall be adopted separately by Parliament according to the procedure referred to in point 2 above.' (The FL was not yet in force when the Parliament adopted the Transitional Provisions - this is the reason for the reference to the former Constitution).

${ }^{60}$ The Constitutional Court annulled approximately half of the articles of the TPFL in its decision of 28 December 2012 [HCC Decision 45/2012. (XII. 29.) AB]. The decision is available at link 3. It is worth mentioning the governing party's response, in which the faction leader immediately declared that the annulled provisions would be inserted into the FL. See also Szente (2013) 11-21. 
regulations into the 'Transitional Provisions of the Fundamental Law' that did not have a transitional character. The Hungarian Parliament should also comply with the procedural requirements when acting as constitution-maker, because any regulations that violate these requirements are invalid. Therefore, the Constitutional Court annulled the regulations concerned due to formal deficiencies. The Constitutional Court, regarding its consistent practice, did not examine the constitutionality of the content of the Fundamental Law and the Transitional Provisions.

As a response, the governing majority adopted the Fourth Amendment of the FL (April 2013), which incorporated into the Constitution most of the abolished articles and overrode several previous Constitutional Court decisions. The Venice Commission expressed its serious concerns about the systematic shielding of ordinary law from constitutional review. The reduction (budgetary matters) and in some cases complete removal (constitutionalised matters) of the competence of the Court to review ordinary legislation on the one hand undermines the rule of law - as the constitutional protection of the standards of the FL have become limited; while on the other hand it infringes the democratic system of checks and balances - as the Constitutional Court has lost its influence and is not able to provide effective control. ${ }^{61}$

The Fourth Amendment introduced lex specialis rules in comparison to the fundamental principles of the rule of law, ${ }^{62}$ democracy and the protection of fundamental rights; regulations evading or bypassing Constitutional Court rulings were enacted, substantially reducing the space for constitutional protection (e.g. student contracts, recognition of churches, concept of family), the specific review - and new interpretation - limit was raised, blocking the way to constitutional judicature (the exclusion of a substantial review of the amendments to the constitution, the repeal of Constitutional Court decisions adopted before the FL), and even the open infringement of EU law (limitation of election campaigns, the possibility of special taxation as an indirect result of court rulings) was risked. ${ }^{63}$ The Fifth Amendment (October 2013) was adopted by the governing majority under the pressure of European institutions with the intention of 'closing international debates'; however, not all of the challenged articles were modified, just those with the potential of infringing EU-law. The Sixth Amendment (July 2016) did not affect the Constitutional Court and its review powers, since it concerned the constitutional regulation of the special legal order. ${ }^{64}$ The most recent Seventh Amendment - which originally failed in 2016 but was reloaded, updated

\footnotetext{
${ }^{61}$ See Opinion № 720/2013 of the Venice Commission point 87 at link 4.

${ }^{62}$ Especially Article U), introduced by this amendment, drew attention as a lex specialis or even an exception to the rule of law principle, as it makes possible the retroactive prosecution of politically motivated crimes committed and not prosecuted during the communist regime.However, Article U) is not present in the case law of the Constitutional Court, and its relation to Article B)(1) was not clarified: there has only been one decision - HCC Decision 16/2014. (V. 22.) $\mathrm{AB}$ - so far which obiter dictum explained that the paragraphs of this article result in a contextual difference between the Fundamental Law and the former Constitution regarding their regulation on the rule of law and the nullum crimen et nulla poena sine lege principle, but the Court did not reach any interpretative conclusion because in the concrete case Article U) was not applicable, being completely irrelevant. See, on this, Hollán (2019) 76.

${ }^{63}$ See to this Vörös (2014) 1-20., Zeller (2013) 307-25., Vincze (2014b) 86-97.

${ }^{64}$ It introduced a new state of emergency in cases of threats or acts of terrorism beyond the existing five special legal order situations: national crisis, emergency, preventive defence, unforeseen intrusion, and danger. There is no room for a thorough analysis, but a short comment seems to be necessary. This regulation still provides wide discretional power to the government, because the constitution allows the introduction of the special legal order even in the case of a terror threat - about which the intelligence agency may have exact information; thus the democratic control on the necessity of the introduction is rather limited.
} 
and adopted by the governing majority after the parliamentary elections in 2018 - prescribed, among others, the protection of constitutional identity based on the historic Hungarian Constitution, prohibited the settlement of foreign citizens, created a basis for sanctioning homelessness, and prescribed the establishment of a separate administrative courts system.

During the past decade, the composition of the Constitutional Court has changed to a great extent. The acting justices take a modest approach to controlling the legislator, and sometimes postpone or bypass decisions in sensitive questions (e.g. in the cases of the Central European University, or the refugee quota).

\section{RULE OF LAW STANDARDS AND THE LEGISLATIVE POWER}

\subsection{Constitutional amendments}

When the Constitutional Court was searching for standards in its Decision 61/2011. (VII. 13.) $\mathrm{AB}$ for the review of the unconstitutional amendment, but did not find any. It did, however, provide obiter dictum important and forward thoughts, even (or already) before the entry into force of the FL. It suggested a potential standard for review by relating some rule of law standards and international ius cogens norms.

The standards, fundamental principles and fundamental values of ius cogens altogether provide a standard that must be met by every subsequent constitutional amendment and Constitution. A larger part of these principles and values has been incorporated into the Constitution and into the case-law of the Constitutional Court, or has become part of the laws of the branches of law (e.g. the formulation of the prohibition of retroactive effect in terms of criminal law, the nullum crimen sine lege principle, the nulla poena sine lege principle or the principle of exercise of rights of good faith, the principle of fair trial, etc. in other branches of law). The principles, and guarantees of ius cogens appear in the form of values in the laws of the branches of law and in other legislation as well. ${ }^{65}$

This part seems to suggest that the Constitutional Court would in general, but not in specific cases, attribute in principle a certain level of 'supraconstitutionality' to the international ius cogens standards, i.e. would consider them as holding an interpretative priority in the course of constitutional judicature. ${ }^{66}$ The quoted thinking is, however, not so convincing: the only positive and - in terms of the law - interpretable argument of the Court as regards the (potential) call for the ius cogens may be its incorporation into domestic law, i.e. its transformation from a supraconstitutional into an intra-constitutional context.

The above-mentioned standards appeared again, although in a form which was much more difficult to decipher and even more blurred, in the Decision on the TPFL, as adopted about a year after the entry into force of the new constitution. The Constitutional Court established in its Decision 45/2012. (XII. 29.) AB that it has the power to review the TPFL, in that it had become a regulation substituting the constitution and disrupting the unity and structure thereof and taking away the scope of competence of the Constitutional Court. The body provided an

\footnotetext{
${ }^{65}$ HCC Decision 61/2011. (II. 13.) AB, ABH 2011, 696, 711.

${ }^{66}$ Blutman (2011) 1-11.
} 
extremely faint reference in this decision to the possibility of an eventual substantial review of future amendments to the FL in comparison with international standards.

Constitutional legality has not only procedural, formal and public law validity requirements, but also substantial ones. The constitutional criteria of a democratic State under the rule of law are at the same time constitutional values, principles and fundamental democratic freedoms enshrined in international treaties and accepted and acknowledged by communities of democratic States under the rule of law, as well as the ius cogens, which is partly the same as the foregoing. As appropriate, the Constitutional Court may even examine the free enforcement and the constitutionalization of the substantial requirements, guarantees and values of democratic States under the rule of law. ${ }^{67}$

International standards are transformed here into a requirement for a democratic state governed by rule of law, and are internalised - without precise reference to their source, origin or scope. However, parliament, exercising the power to amend the constitution, found this indirect reference more than enough - the Fourth Amendment closed the path to any substantial review of future amendments. Upon the motion of the Commissioner of Fundamental Rights, the Constitutional Court undertook to review this amendment, but no invalidity was found by Decision 12/2013. (V. 24.) AB.

\subsection{Legislation and legal certainty}

Rule of law requirements can be reviewed in terms of the legislative procedure, as well as in terms of the 'products of the legislation', the legal acts. This section focuses on the latter issue, because the Constitutional Court provides only a narrow protection against legislative failures (e.g. in cases of abuse of the parliamentary procedural rules, or failure to carry out a preliminary consultation) except in the case of public law invalidity and the violation of qualified majority rules. $^{68}$

In the last decade, reference to the principle of rule of law seems to have been increasingly relegated to the background in the Constitutional Court's decisions in constitutional complaint procedures, and in other constitutional judicial review cases, as well. The Court protects the principle of the rule of law to a very narrow extent in constitutional complaint procedures, i.e. as far as the lack of required preparation time and the prohibition of adverse retroactive effects are concerned, but not as far as the course of constitutional complaint procedures are concerned. ${ }^{69}$ The protection of acquired rights and the protection of legitimate expectations (Vertrauensschutz) are completely disappearing. ${ }^{70}$

As Table 1 shows, the proportion of constitutional complaint procedures among all constitutional review procedures is increasing year by year. After the entry into force of the FL, the Constitutional Court confirmed that the constitutional requirement of the rule of law and

\footnotetext{
${ }^{67}$ HCC Decision 45/2012. (II. 29.) AB, ABH 2012, 347, 403. para [118]

${ }^{68}$ For a thorough analysis, see Kazai (2019) at link 5. Evaluating HCC Decision 16/2015. (VI. 5.) AB, Kazai points out: 'One of the interesting features of the decision was that the procedural invalidity of the provision was not derived from the rule of law principle [Article B) (1)], but from those constitutional rules which required the regulation of the legislative matter by a two-thirds majority [Articles P) (2) and 38 (1)].'

${ }^{69}$ Originally: HCC Order 1140/D/2006 AB, but at the time the 1989 Constitution was in force, this did not represent a problem due to the actio popularis type ex post constitutional review.

${ }^{70}$ See, early retirement - HCC Decision 23/2013. (IX. 25.) AB; gambling monopoly - HCC Decision 26/2013. (X. 4.) AB.
} 
Table 1. On the proportion of constitutional complaint procedures. Source of the table: Justice Ágnes Czine's presentation ${ }^{71}$

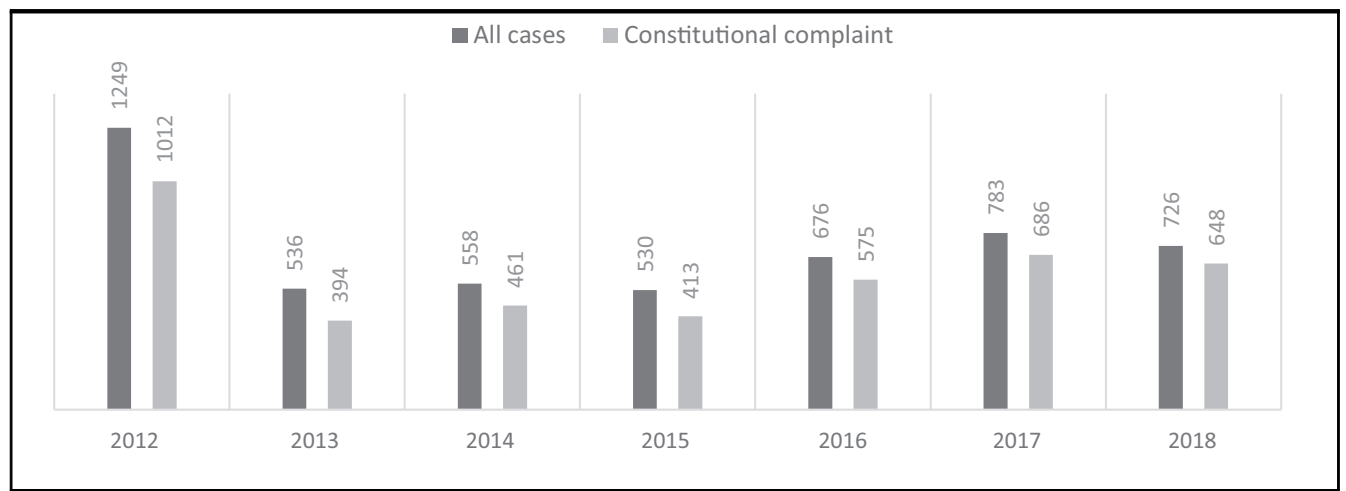

legal certainty as set out in Article B)(1) of the FL can be invoked in constitutional complaint proceedings solely in cases of retroactive effect and when there is a lack of sufficient or required preparation time. ${ }^{72}$ Other features of the rule of law principle cannot be invoked, because Article B)(1) of the FL does not contain any rights guaranteed by the FL. ${ }^{73}$

An interesting interrelated effect of the procedural changes can be that as the complainants cannot successfully refer to the rule of law principle in Article B) of the FL they tend to refer to the violation of the right to fair trial in Article XXVIII(1) of the FL instead (see Table 2).

Table 2. On petitioners' reference practice. Source of the table: Justice Ágnes Czine's article ${ }^{74}$

\begin{tabular}{|l|c|c|}
\hline Year & $\begin{array}{c}\text { Art. B) para. (1) of FL in the constitutional } \\
\text { complaints }\end{array}$ & $\begin{array}{c}\text { Art. XXVIII para. (1) of FL in the constitutional } \\
\text { complaints }\end{array}$ \\
\hline 2012 & 294 & 164 \\
\hline 2013 & 112 & 117 \\
\hline 2014 & 460 & 563 \\
\hline 2015 & 1,426 & 1,566 \\
\hline 2016 & 288 & 571 \\
\hline 2017 & 224 & 1,171 \\
\hline 2018 & 157 & 436 \\
\hline Total & 2,961 & 4,588 \\
\hline
\end{tabular}

\footnotetext{
${ }^{71}$ Link 6.

${ }^{72}$ HCC Decision 3062/2012. (VII. 26.) AB, Reasoning [171]

${ }^{73}$ HCC Decision 3047/2016. (III. 22.) AB, Reasoning [39]

${ }^{74}$ Link 7.
} 
Although the presence of the rule of law and legal certainty argumentation is in quantitative decline in the decisions, the Constitutional Court still refers to or even quotes pre-FL statements on legal certainty, predictability in the application of the laws and in legal proceedings, clarity of legal norms, required and sufficient preparation time or the prohibition of adverse retroactive effects - but rarely declares unconstitutionality solely upon that basis, or reaches surprising and embarrassing conclusions. In politically sensitive cases, instead of declaring the regulation void the Court often opts for formulating a constitutional requirement to orient the law application of ordinary courts. Let us consider some examples.

In the consumer loan agreements case ${ }^{75}$ on 11 November 2014, the Constitutional Court rejected the petitions of the judges of the Budapest-Capital Regional Court. In its decision the Constitutional Court declared that the challenged provisions of the Act, which described the consequences of the application of unfair clauses which amended bank loan agreements unilaterally did not violate the FL. Taking the petitions into consideration, the Constitutional Court examined primarily whether the prohibition of retroactive legislation had been violated by the provisions of the challenged Act and whether the rules of the judicial procedures concerned were in compliance with the requirement of a fair trial. In connection with the prohibition of retroactive legislation, the Constitutional Court declared that the general legal requirements of good faith and a fair trial had always been the limits of the unilateral modifications of the agreements. However, the enabling provisions of the Act on Credit Institutions did not repeal or suspend the requirement of a fair trial. Although the interpretation in connection with the concrete conditions of the fair unilateral modification of the agreements was adopted only later into the Opinion of the Civil Department, into the Uniformity Decision of the Curia and finally into the challenged Act, these requirements were already deducible from the general background legal provisions. The standard of fairness was not changed; since although it was expressively set out in the challenged Act, it had already been a requirement (based on the previous Civil Code and on the judicial practice) before. In other terms, the challenged regulation did not change the legal qualification of the unfair clauses of the contracts; it only codified the existing legal background and jurisprudential practice. The thirty days provided to the financial institutions to initiate the proceeding at the court cannot be considered an unnecessary or disproportionate limitation of fundamental rights. The deadline provided should be sufficient for the financial institutions concerned to decide on the commencement of any action to rebut the presumption of unfairness. In order to prepare for the action, the plaintiffs were entitled to use the arguments and evidence from the previous actions against them. In connection with the other short deadlines, the Constitutional Court declared that these deadlines should not be considered infeasible. $^{76}$

In the Questor-case ${ }^{77}$ the Constitutional Court examined the Act on compensation for the victims of the collapsed Quaestor brokerage house. ${ }^{78}$ The Act issued by the governing majority

\footnotetext{
${ }^{75}$ HCC Decision 34/2014. (XI. 14.) AB, on the examination of certain provisions of Act XXXVIII of 2014 on Settlement of Certain Issues Related to the Uniformity Decision of the Curia on the Consumer Loan Agreements Provided by Financial Institutions

${ }^{76}$ See on this Gárdos-Orosz (2018) 94-118.

${ }^{77}$ HCC Decision 32/2015. (XI. 19.) AB.

${ }^{78}$ See Novak (2015) at link 8.
} 
promised all the victims compensation for losses up to HUF 30 million per person, despite the fact that Hungarian law only provides for HUF 6 million of compensation, and this was the amount offered to the victims of previous brokerage house collapses. Because the victim compensation fund had already been largely depleted as a result of compensating the victims of earlier scandals, the law required financial brokerage firms and banks trading in securities to advance sufficient funds to cover most of the projected outlays. The banks responded by filing a petition to the Constitutional Court. In addition to arguing that it was wrong to require them to compensate the victims of a former competitor which had acted irresponsibly or even criminally, they also pointed out that it was unfair to compensate Quaestor victims up to five times more than victims of other cases. They also referred to the insufficient preparation time. The Constitutional Court recalled its former case law by referring to HCC Decision 28/1992 (IV. 30.) AB: 'A democratic state under the rule of law [...] is, among many others, different from a dictatorship in [such] a way that it provides guarantees for the legal entities to be genuinely aware of and able to comply with the legal provisions that govern them. The date of entry into force of the [...] act shall be fixed so as to allow time (a) to obtain the text of the act and to study it; (b) for law enforcement bodies to prepare for the application of the law; (c) for persons and bodies subject to the law to decide how to comply with the law.' These criteria have been reaffirmed by the Constitutional Court, even after the Fourth Amendment to the FL in HCC Decision 34/2014. (XI. 14.) AB, reasoning [58]. The Court found that in the case concerned, a short period of time - 1 day - had passed between the submission of the bill and the entry into force of the Act; however, this circumstance, in the view of the Constitutional Court's practice, does not in itself justify a declaration of unconstitutionality. The Constitutional Court held however, that the exact amount, timing and duration of the advance payment requested by the Quaestor Fund's Board of Directors on the basis of the Act was not clear to those concerned, including petitioners. Interested parties would only have the opportunity to know the exact amount of their obligation when the advance payment was requested or determined by the Quaestor Fund Board. The amount of the obligation could not be deduced from the text of the Act; it could only be estimated. It also follows from the requirement of sufficient preparation time, taking into account the consistent practice of the Constitutional Court, that the additional obligation introduced by the new norm must be precisely defined. Infringement of the requirement of sufficient lead time can therefore be established not only in the context of clear regulation but also when the obligation is not clearly defined. Upon that basis the Constitutional Court declared the Act unconstitutional.

In the decision on homelessness, ${ }^{79}$ the Constitutional Court rejected the judicial initiatives challenging the provisions of the Act on Offences which prohibited staying habitually on public ground. The Constitutional Court stated as a constitutional requirement that the challenged sanction under the Act shall only be applicable if a placement for the homeless person had been verifiably granted prior to the time the conduct was committed. The petitioning judges held the challenged provisions to be contrary to the principle of the rule of law as well as to the right to human dignity. They referred to a decision of the Constitutional Court adopted in 2012 annulling a statutory definition of a minor offence of essentially similar content - as well as to the text of the Fundamental Law amended in the meantime, which does not justify the

${ }^{79}$ HCC Decision 19/2019. (VI. 18.) AB. 
criminalisation of staying habitually on public ground. Amongst other arguments, the requirement of the clarity of norms was also referred to by the petitioners, who alleged that the regulation which empowers police to order homeless people into shelters and to arrest them if they disobey after being ordered three times within a 90-day period, is not clear enough, because the three police orders can occur on the same day, or even within hours of each other. The Constitutional Court emphasized that it would follow the text in force of the Fundamental Law, and it is not empowered to review the content of the Fundamental Law or the amendments of the Fundamental Law. In the course of exercising his or her constitutional rights, the individual is responsible not only for himself or herself, but also for the other members of the community; the exercising of rights should be in balance with his or her responsibility to the community. According to the decision, the challenged regulation complies with the constitutional requirement applicable to the law on minor offences, and also enforces its guarantees. The regulation imposes a sanction against anyone who refuses to desist from staying habitually on public ground despite the relevant prohibition laid down in the Fundamental Law and despite receiving multiple explicit warnings. Therefore, the relevant statutory definition of the offence does not sanction a state (i.e. of being homeless), but it imposes a legal consequence on violating the obligation to cooperate. Concerning the alleged violation of the clarity of norms and the potential arbitrary application of law, the Court stated that the difficulties stemming from the formulation of a legal provision only raise legal uncertainty and render unavoidable the annulment of a provision where the legislation is initially uninterpretable, and renders its application unpredictable for the addressees of the provision. It is not possible to describe the legal notion of habitual dwelling in a comprehensive list, and it would be contrary to the purpose of the legislation, since only a careful consideration of all the circumstances can determine whether there is in fact a case of public dwelling. This is the task of the law enforcement agencies and courts to decide on a case by case basis. The provision on three orders is not an infringement of the requirement of the clarity of legal norms. ${ }^{80}$

The Constitutional Court, in its decision 3/2019. (III. 7.) AB decided on the constitutionality of certain elements of the Stop Soros legislative package and ruled that the criminalization of 'facilitating illegal immigration' does not violate the Fundamental Law. As the Venice Commission and OSCE pointed out in a joint opinion when they evaluated the draft, the new Article of the Hungarian Criminal Code criminalises organisational activities which are not directly related to the materialization of illegal migration, such as 'preparing or distributing informational materials'. This, on the one hand, runs counter to the role of assistance to victims by NGOs, restricting disproportionally the rights guaranteed under Article 11 ECHR, and on the other hand, criminalises advocacy and campaigning activities, which constitute an illegitimate interference with the freedom of expression guaranteed under Article 10 ECHR. ${ }^{81}$ According to the decision of the Constitutional Court, with appropriate judicial interpretation the criminal offence of facilitating illegal immigration should not be considered as having occurred if the aim of the activity is limited to the mitigation of the sufferings of those in need and to the humanitarian treatment of such persons. To reinforce this, the Constitutional Court laid down as a constitutional requirement that the new statutory definition not be applicable to the altruistic

\footnotetext{
${ }^{80}$ HCC Decision 19/2019. (VI. 18.) AB, Reasoning [81].

${ }^{81}$ Link 9. para. 101.
} 
conducts that perform the obligation of helping the vulnerable and the poor. However, despite the convincing arguments of the petition, the Court did not find that the formulation of the criminal offence violates the clarity-requirement. ${ }^{82}$ The Court instead referred to the constitutional requirement to protect Hungary's sovereignty and constitutional identity to justify the anti-immigration policy of the government. ${ }^{83}$

\section{JUDICIAL INDEPENDENCE}

The independence of the judiciary and judges is of paramount importance from the perspective of the democratic rule of law principle. After the adoption of the new constitution, the twothirds majority also challenged the judicial branch of power in many ways. First, the legislator lowered the retirement age of judges from 70 to 62 years. Since 1869, Hungarian judges have been allowed to remain in office beyond the retirement age, thus they could freely choose their day of retirement between the age of 62 and $70 .{ }^{84}$ However, the FL and Act 162 of 2011 on the legal status of judges unexpectedly obliged them to retire at the general retirement age from the beginning of 2012. ${ }^{85}$ This led to a mass removal of over 270 judges in the first half of 2012 .

Second, in the course of the constitutional and judicial reform, the Supreme Court was renamed the Curia (in Hungarian Kúria, which is the historical name of the highest judicial body), without any significant changes regarding its competences, however, the TPFL terminated the mandate of the President of the Supreme Court, who was elected by the Parliament in 2009 for a 6 year term. ${ }^{86}$ The President of the Supreme Court earlier criticized the premature retirement of judges and other supermajority actions concerning the independence of the judiciary.

Third, before the FL, the administration of justice had been based on autonomy and judicial independence. In 2011 the reforms aiming to improve efficiency placed the administrative powers held by the National Council of Justice and its president (the President of the Supreme Court) in the hands of two new bodies - the National Judicial Office and the National Judicial Council. While the Council provides mostly control and consultative functions, the latter exercises the effective administrative competences over the judiciary. The President of the NJO originally had a vast array of competences relating to judicial appointments, case allocation, administration, management and supervision, and thus this extensive power over the judiciary belonged to a politically-appointed individual. However, following widespread alarm expressed by both the national and international community regarding these powers and their impact on the independence of the judiciary, in 2012 the parliament restricted certain of the competences of the President of the NJO and increased those of the NJC.

Fourth, the so called Nullity act, Act XVI of 2011 on the redress of the court judgments related to crowd control issues in the autumn of 2006, nullified certain judgments relating to the

\footnotetext{
${ }^{82}$ On the ambiguous practice of the Constitutional Court regarding the clarity of norms doctrine, see Ficsor (2018) 271289.

${ }^{83}$ HCC Decision 3/2019. (III. 7.) AB, Reasoning [43].

${ }^{84}$ See also Fekete (2015) 169-86.

${ }^{85}$ Gyulavári and Hös (2013) 289.

${ }^{86}$ Vincze (2014a) 204.
} 
civil unrest of autumn 2006, ${ }^{87}$ on the basis that the law interfered with the right of judges (rather than the legislature) to assess evidence and decide on individual cases. The act suggested that the police gave false evidence in each case when it was their evidence alone which confirmed the act had been committed; in these cases the prosecutors had wrongly brought charges, and that the judgments of the first and second instance were wrong.

Fifth, by the Seventh Amendment to the FL (2018) the governing majority decided to reestablish the separate system of Administrative Courts. ${ }^{88}$ The new system would have reformed the mixed system consisting of 'Administrative and Labour Courts', which did not form a special branch of courts but functioned as a sort of decentralised unit of the second lowest layer of the ordinary courts, while the highest level in administrative matters was the Kúria, the ordinary Supreme Court. The minister of justice lodged the bills on the new system on 6 November 2018. Under the planned new regulation, the present administrative judges could opt into the new system, and new judges with significant administrative, but limited judicial, practice might also be appointed. The President of the Supreme Administrative Court would have been elected by the Parliament by the end of March 2019. The new system - with a Supreme Administrative Court and eight regional administrative courts - was to be set up by January 2020. The Acts on the reform were criticised for allowing the executive branch to have a wider influence on administrative courts than on ordinary courts. The competences related to the administration of justice - especially budgetary matters and judicial appointments - would belong to the minister of justice in the case of administrative courts, thus this model was designed to be different from the administration of ordinary courts in Hungary. In a state governed by the rule of law a professional and independent system of administrative courts may contribute to effective judicial protection; however, if the interrelated requirements of the rule of law are not observed in a state then a separate court cannot balance the overwhelming powers of the executive. Finally, before the 2019 European Parliamentary elections the complete reform was postponed and then the new acts were repealed, together with the relevant parts of the Seventh Amendment (Eights Amendment of the FL, 2019), although in the meantime the constitutionality of these laws had been challenged before the Constitutional Court. At the end of 2019, a modest reform was carried out within the system of ordinary courts regarding the administrative branch and the last instance remained the Kúria in administrative cases.

These issues raised international criticism and ended in procedures before the Constitutional Court. In most cases the Court argued solely upon the domestic constitutional basis and did not refer to the European values of rule of law.

The radical lowering of the retirement age of judges in 2012 was the subject of the constitutional appeal leading to the first declaration of unconstitutionality. ${ }^{89}$ The main argument of the body in this matter was the irremovability implied by judicial independence, which means

\footnotetext{
${ }^{87}$ On 18 September 2006 a massive demonstration was held near the Hungarian Parliament. The protests, allegedly attended by 40,000 people, concerned the audio recording which surfaced on 17 September 2006, on which the then Prime Minister Gyurcsány admitted to lying to the public for a couple of years, including lying about the budget deficit. Police violence during the crowd control ended in criminal or offence procedures.

${ }^{88}$ The Hungarian Royal Administrative Court was established in 1896 (Act XXVI of 1896) and functioned until 1949. It was a one-instance court, and operated in a completely different legal environment than the proposed administrative court system, thus it is hardly comparable with the 2018 proposals.

${ }^{89}$ HCC Decision 33/2012. (VII. 17.) AB, ABH 2012, 242.
} 
that the retirement age may be lowered gradually, and only with a necessary transition period. The decision was dominated by internal argumentation on basis of domestic constitutional law, and only one of the relevant recommendations of the Council of Europe ${ }^{90}$ appeared to provide suitable support, though it was known that the CJEU was also dealing with the case as initiated by the European Commission. The Constitutional Court did, however, avoid involving the issue of age discrimination in the review, and it did not seek assistance in the law of the EU to interpret the amendments of the new constitution in the TPFL, nor seek direct contact with the Luxembourg court through initiating a preliminary ruling procedure. The impropriety of the ostrich policy and the insufficiency of the pro futuro nullification was even further highlighted by the decision of the $\mathrm{CJEU}^{91}$ a few months later. ${ }^{92}$ Although the Hungarian Constitutional Court declared the unconstitutionality of the measure, it failed to repair the infringement of the affected judges' fundamental rights.

The premature termination of the mandate of the President and Vice President of the Supreme Court is also related to the transformation of the judicial organisation. Whereas the mandate of the President of the Supreme Court was terminated by the TPFL, ${ }^{93}$ only the Vice President could lodge a constitutional appeal, and his term was terminated pursuant to the Act on the organisation and administration of courts. The Constitutional Court found, with a narrow 8 to 7 majority, that the transformation of the organisation of courts and the significant modification of the scope of responsibilities of the Kúria (Curia), its president and vice president, provided sufficient constitutional justification for the shortening of their mandates, and did not require a review of the relevant Strasbourg jurisprudence. ${ }^{94}$ According to those Constitutional Court judges who gave a dissenting opinion, prejudice to the rule of law and violation of the right to remedies of the petitioner should have been established. Comparatively, the ECtHR stated, on the basis of the complaint of the President of the Supreme Court, that the State of Hungary had infringed the right to a fair trial in that it had not ensured any judicial revision in the case. Moreover, the right of the President of the Supreme Court to free expression had also been infringed, in that his removal may have been related to his criticism concerning the transformation of the organisation of courts, which had not been only his right but - as a court leader - his obligation as well. ${ }^{95}$

In the decision on case allocation, which belonged to the competences of the President of the National Judicial Office, the Constitutional Court held that the right to an appointed judge and the prohibition on an appointed judge being removed to be basic requirements for a fair trial, and concluded that the appointment of the members of the proceeding court at the sole discretion of the President of the National Judicial Office does infringe these rights, and that the

\footnotetext{
${ }^{90}$ Recommendation $\mathrm{CM} / \operatorname{Rec}(2010) 12$ of the Committee of Ministers to member states on judges: independence, efficiency and responsibilities. Quoted by HCC Decision 33/2012. (VII. 17.) AB, ABH 2012, 242, 248.

${ }^{91}$ Case C-286/12, Commission v Hungary, Judgment of 6 November 2012, ECLI:EU:C:2012:687.

${ }^{92}$ See also Vincze (2013) 324-25.

${ }^{93}$ Point 14(2) of the Closing and miscellaneous provisions of the FL: The mandate of the President of the Supreme Court and of the President and members of the National Council of Justice shall terminate upon the entry into force of the Fundamental Law.

${ }^{94}$ HCC Decision 3076/2013. (III. 27.) AB, ABH 2013, 434, 439.

${ }^{95}$ Baka v. Hungary, Judgement of 27 May 2014, no. 20261/12, § 79, 100, 103.
} 
legal regulation does not meet the so-called objective test of an impartial judiciary. ${ }^{96}$ The Court heroically declared the rules no longer in force, but still having an effect on the cases of the petitioners, to be unconstitutional and in conflict with international treaties, and provided subjective protection of fundamental rights as befits the function of a constitutional appeal. The Court's reasoning provided extensive references to the relevant jurisprudence of the ECtHR, and it also took into consideration the relevant, and sharply critical, positions of the Venice Commission.

The picture would not be complete without mentioning the fact that the independence of the judicial branch and the principle of the rule of law suffered a severe defeat from the rather obscure argument about justice in the Constitutional Court decision on the Nullity Act, in which the reasoning considered foreign solutions only, and European standards did not appear to be included in the reasoning. ${ }^{97}$ The Court found the Act of Parliament on annulling the judgments of the courts of law justifiable and constitutional in the given historical circumstances, which is clearly an argument beyond constitutional law.

Although the government decided to postpone and later to withdraw the establishment of separate Administrative Courts in order to avoid EU criticism, the Constitutional Court, upon the request of one quarter of the Members of Parliament, examined the constitutionality of the related Acts. ${ }^{98}$ The petitioners alleged that there had been a violation of the rules on the preparatory period, on the separation of powers, and of the requirement of the impartiality and the unbiased decision making of the adjudicating judges. According to the press release: 'In the course of examining the modified and amended Acts, the Constitutional Court based its review on the fact that although judicial independence is an achievement of our historical constitution, ${ }^{99}$ it is not identical with the complete administrative independence of the court system providing the framework for the judicial activity. There are several models of court administration (the ministerial model, administration through judicial councils, the mixed model, and various versions of the foregoing). Therefore, an emphasis should be put on guaranteeing that the administration only affects the structural operation of the courts (for example, in which settlements is it justified to have a court, or the number of the staff) without influencing the merits of their professional operation, namely the adjudicating activity, together with the related independence of the judges and of the court system. The distinction made in principle between the adjudicating activity and the external administration of the courts as organisations is an achievement of our historical constitution. However, administration is an activity of a specifically executive character. The administration of courts is a duty of public administration entrusted on the executive power. Administration by the minister, in itself, should violate neither the principle of the separation of powers, nor judicial independence. As long as the administrative activity of the minister does not exercise a direct influence on the professional operation - namely on the adjudicating activity -, no conflict with the Fundamental Law may be established. ${ }^{100}$

\footnotetext{
${ }^{96}$ HCC Decision 36/2013. (XII. 5.) AB, upon normative appeal, with eight dissenting opinions.

${ }^{97}$ HCC Decision 24/2013 (X. 4.) AB.

${ }^{98} \mathrm{HCC}$ Decision 22/2019. (VII. 5.) AB.

${ }^{99}$ And just obiter dicta recalled that judicial independence is one of the foundations of the rule of law, Reasoning [60].

${ }^{100}$ HCC Decision 22/2019. (VII. 5.) AB. For press release see link 10.
} 
This case law line is selective but indicates the constant pressure from the side of the governing majority on the judicial branch, and the manoeuvres of the Constitutional Court to balance it. What is remarkable is that judicial independence, which is equally important from the perspective of the principles of the rule of law and the separation of powers, seems to have moved to the uncertain field of the achievements of the historical constitution.

\section{CLOSING REMARKS}

Although it also defines Hungary as a 'state under the rule of law', the entry into force of the Fundamental Law has brought about a change in the intensity of the constitutional protection of this significant principle. The rule of law, although present in the argumentation of the Constitutional Court, is less 'spectacular' compared to the 1990s. The rule of law requirements for procedural guarantees and procedural safeguards continue to be somewhat protected, ${ }^{101}$ but legal certainty and the protection of acquired rights often seem to be neglected. This can be attributed partly to the repositioning of constitutional justice, the abolition of the actio popularis right of petition, which has led to a reduction in the number of abstract norm-control procedures, and the fact that in constitutional complaint proceedings, the Court protects the rule of law only to a limited extent, taking into account the lack of sufficient preparation time and the prohibition of retroactive effect. But the constitutional environment of the illiberal state also has an overwhelming influence on the rule of law interpretation, and disrupts the development of the rule of law case law and initiates the introduction of new concepts (such as achievements of the historical constitution and constitutional identity protection).

The purpose of the Constitutional Court is not a strict rule of law review in the light of the heritage of the pre-2010 case law; instead, it opts for an understanding of the objectives of the legislator and finds out how to justify them through the Fundamental Law. This approach leads to the upholding a kind of pragmatic legality but does not maintain the substance of the democratic state governed by the rule of law.

\section{LITERATURE}

Blutman, L., 'Az Alkotmánybíróság és az alkotmány feletti normák: könnyü liaison elkötelezettség nélkül?’ (Constitutional Court and Supra-constitutional Norms: An Airy Liaison Without Commitments?) (2011) 4 Közjogi Szemle 1-11.

Chronowski, N., 'The Fundamental Law Within the Network of Multilevel European Constitutionalism' in Szente, Z. and others (eds), Challenges and Pitfalls in the Recent Hungarian Constitutional Development (L'Harmattan 2015) 223-40.

\footnotetext{
${ }^{101}$ E.g. procedural failures in the legislative process, HCC Decision 6/2013. (III. 1.) AB, Reasoning [63-72]; dismissal without reasoning, effective judicial protection, HCC Decision 34/2012. (VII. 17.) AB; invalidity under public law, constitutional matters, HCC Decision 45/2012. (XII. 29.) AB; protection of qualified majority legislation, HCC Decision 1/2017. (I. 17.) AB; rule of law and right to remedy, HCC Decision 2/2013. (I. 23.) AB; predictability of law application, obligation to give a reasoning, HCC Decision 13/2013. (VI. 17.) AB; procedural guarantees against secret national security surveillance, HCC Decision 19/2013. (VII. 19.) AB; but the rule of law argument was not strong enough in the case of Nullity Act, 24/2013. (X. 4.) AB.
} 
Chronowski, N., Human Rights in a Multilevel Constitutional Area. Global, European and Hungarian Challenges (L'Harmattan 2018).

Chronowski, N. and Varju, M., 'The Hungarian rule of law crisis and its European context' in Kellerhals, A., Baumgartner, T. (eds), Rule of Law in Europe - Current Challenges (Schulthess 2017) 149-68.

Chronowski, N. and Varju, M., 'Two Eras of Hungarian Constitutionalism: From the Rule of Law to Rule by Law' (2016) 8 (2) Hague J Rule Law 271-89.

Chronowski, N. and Vincze, A., 'Önazonosság és európai integráció - az Alkotmánybíróság az identitáskeresés útján' (Constitutional Identity and European Integration - Brand New Findings of the Hungarian Constitutional Court) (2017) 72 Jogtudományi Közlöny 117-32.

Csink, L., Schanda, B. and Varga, Zs. A. (eds), The Basic Law of Hungary. A First Commentary (Clarus Press 2012).

Fekete, B., 'How to Become a Judge in Hungary? From the Professionalism of the Judiciary to the Political Ties of the Constitutional Court' in Turenne, S. (ed), Fair Reflection of the Society in Judicial Systems: A Comparative Analysis (Springer 2015) 169-86.

Ficsor, K., 'Certainty and Uncertainty in Criminal Law and the "Clarity of Norms' Doctrine”' (2018) 59 (3) Hungarian Journal of Legal Studies 271-89.

Gárdos-Orosz, F. 'Constitutional Justice in Credit Crises. The Hungarian Case' (2018) 66 Südosteuropa 94-118.

Győrfi, T. and Jakab, A., 'Jogállamiság' (Rule of Law) in Jakab, A. (ed) Az Alkotmány kommentárja (Commentary of the Constitution) (Századvég 2009) 155-211.

Gyulavári, T. and Hős, N., 'Retirement of Hungarian Judges, Age Discrimination and Judicial Independence: A Tale of Two Courts' (2013) 42 (3) Industrial LJ 289-97.

Halmai, G., 'The Coup Against Constitutional Democracy. The Case of Hungary' in Graber, M., Levinson, S., Tushnet, M. (eds), Constitutional Democracy in Crisis? (OUP 2018a) 243-256.

Halmai, G., 'The Rise and Fall of Constitutionalism in Hungary' in Blokker, P. (ed), Constitutional Acceleration within the European Union and Beyond (Routledge 2018b) 217-33.

Halmai, G., 'Abuse of Constitutional Identity. The Hungarian Constitutional Court on Interpretation of Article E) (2) of the Fundamental Law' (2018c) 1 Review of Central and East European Law 23-42.

Hollán, M., 'Büntetőbírói döntések az Alkotmánybíróság ítélőszéke előtt a nullum crimen et nulla poena sine lege elv tükrében' (Criminal Court Judgments Before the Constitutional Court in the Light of Nullum Crimen et Nulla Poena Sine Lege Principle) in Az Alaptörvény érvényesülése a bírói gyakorlatban (The Fundamental Law in Judicial Practice) (HVG-ORAC 2019) 64-97.

Jakab, A. and Sonnevend, P., 'Continuity with Deficiencies: The New Basic Law of Hungary' (2013) 9 EuConst 102-38.

Kelemen, K., 'The New Hungarian Constitution: Legal Critiques from Europe' (2017) 1 Review of Central and East European Law 1-49.

Kovács, K. and Tóth, G. A., 'Hungary's Constitutional Transformation' (2011) 7 EuConst 183-203.

Krygier, M., 'Rule of Law' in Rosenfeld, M. and Sajó, A. (eds), The Oxford Handbook of Comparative Constitutional Law (OUP 2012) 233-50.

Küpper, H., Ungarns Verfassung vom 25. April 2011. Einführung - Übersetzung - Materialien (Peter Lang 2012).

Mészáros, G., 'Carl Schmitt in Hungary: Constitutional Crisis in the Shadow of Covid-19' (2021) 1 Review of Central and East European Law 69-90.

Pap, A. L., Democratic Decline in Hungary. Law and Society in an Illiberal Democracy (Routledge 2018).

Petrétei, J., Magyarország alkotmányjoga I. (Constitutional Law of Hungary I) (Kodifikátor 2013). 
Sólyom, L., 'Introduction to the Decisions of the Constitutional Court of the Republic of Hungary' in Sólyom, L., Brunner, G. (eds), Constitutional Judiciary in a New Democracy, The Hungarian Constitutional Court (University of Michigan Press 2000) 1-38.

Sólyom, L., 'The Rise and Decline of Constitutional Culture in Hungary' in von Bogdandy, A., Sonnevend, P. (eds), Constitutional Crisis in the European Constitutional Area (Hart 2015) 5-31.

Szente, Z., 'Az Alkotmánybíróság döntése Magyarország Alaptörvényének Átmeneti rendelkezései alkotmányosságáról: az Alaptörvény integritása és az alkotmányozó hatalom korlátai' (The Decision of the Constitutional Court on the Constitutionality of the Transitional Provisions of Fundamental Law of Hungary: the Integrity of the Fundamental Law and the Limits of Constitution-making Power) (2013) 4 (1) Jogesetek Magyarázata 11-21.

Szente, Z., 'The Decline of Constitutional Review in Hungary - Towards a Partisan Constitutional Court?' in Szente, Z. and others (eds), Challenges and Pitfalls in the Recent Hungarian Constitutional Development (L'Harmattan 2015) 185-210.

Szente, Z., Mandák, F., Fejes, Zs. (eds), Challenges and Pitfalls in the Recent Hungarian Constitutional Development (L'Harmattan 2015).

Tóth, G. A., Túl a szövegen. Értekezés a magyar alkotmányról (Beyond the Text. Essay on the Hungarian Constitution) (Osiris 2009).

Tóth, G. A. (ed), Constitution for a Disunited Nation - on Hungary's 2011 Fundamental Law (CEU Press 2012).

Trócsányi, L., The Dilemmas of Drafting the Hungarian Fundamental Law (Schenk Verlag 2016).

Varga, Zs. A., Patyi, A. and Schanda, B., The Basic (Fundamental) Law of Hungary. A Commentary of the New Hungarian Constitution (Clarus and NUPS 2015).

Varju, M. and Chronowski, N., 'Constitutional backsliding in Hungary' (2015) 6 TvCR 296-310.

Vincze, A., 'Der EuGH als Hüter der ungarischen Verfassung' (The CJEU As the Guardian of the Hungarian Constitution) (2013) 48 Europarecht 323-33.

Vincze, A., 'Judicial independence and its guarantees beyond the nation state - some recent Hungarian experience' (2014a) 56 Journal of the Indian Law Institute 202-15.

Vincze, A., 'Wrestling with Constitutionalism: the supermajority and the Hungarian Constitutional Court' (2014b) 8 ICL Journal 86-97.

Vincze, A., 'Dismissal of the President of the Hungarian Supreme Court: ECtHR Judgment Baka v. Hungary' (2015) 21 European Public Law 445-56.

Vincze A., Varju, M., 'Hungary: The New Fundamental Law' (2012) 18 European Public Law 437-53.

Vörös, I., 'The constitutional landscape after the fourth and fifth amendments of Hungarian Fundamental Law' (2014) 55 Acta Juridica Hungarica/Hungarian Journal of Legal Studies 1-20.

Zeller, J., 'Nichts ist so beständig. . . Die jüngsten Novellen des Grundgesetzes Ungarns im Kontext der Entscheidungen des Verfassungsgerichts' (2013) 59 Osteuropa Recht 307-25.

\section{LINKS}

1 Halmai, G. and Scheppele, K. L. (eds), Amicus Brief for the Venice Commission on the Transitional Provisions of the Fundamental Law and the Key Cardinal Laws, February 2012, available at $\leq$ https://sites.google. com/site/amicusbriefhungary/> accessed 1 June 2020.

2 Press release on the petition of the Ombudsman lodged in March, 2012 to the Constitutional Court concerning the TPFL, available at http://www.ajbh.hu/en/web/ajbh-en/press-releases/-/content/ujPUErMfB9lw/ 
petition-of-the-ombudsman-to-the-constitutional-court-concerning-the-transitional-provisions-of-thefundamental-law $>$ accessed 7 June 2020.

3 HCC Decision 45/2012. (XII. 29.) on the unconstitutionality and annulment of certain provisions of the Transitional Provisions of the Fundamental Law of Hungary <https://hunconcourt.hu/uploads/sites/3/2017/ 11/en_0045_2012.pdf> accessed 30 May 2020.

4 Opinion № 720/2013 of the Venice Commission on the Fourth Amendment of the Fundamental Law of Hungary, Strasbourg 17 June 2013, available at <www.venice.coe.int/webforms/documents/?pdf $=$ CDL-AD\% 282013\%29012-e> accessed 21 June 2020.

5 Kazai, V. Z., 'The Illiberal Challenge to the Rule of Law Principle: The Neglected Procedural Aspect (With Special Focus on Hungary)' (2019) ESIL Annual Research Forum, Göttingen, 4-5 April 2019, available at SSRN <https://ssrn.com/abstract $=3513204>$ accessed 15 January 2020.

6 Justice Ágnes Czine's presentation at AIDA 2019 session, available at <https://www.aidahungary.org/wpcontent/uploads/2019/12/Biztos\%C3\%ADtas_2019dec12.pdf> accessed 1 June 2020.

7 Czine, Á., 'The Fair Trial on Balance' (2019) SSRN Paper 10.2139/ssrn.3336836 available at <https://ssrn.com/ abstract $=3336836>$ accessed 1 June 2020 .

8 Novak, B., 'Quaestor compensation law struck down by Constitutional Court' The Budapest Beacon, 18 November 2015, available at $\leq$ https://budapestbeacon.com/quaestor-compensation-law-struck-down-byconstitutional-court/> accessed 1 June 2020.

9 CDL-AD(2018)013, Joint opinion of Venice Commission and OSCE/ODIHR on the provisions of the so called 'Stop Soros' draft legislative package which directly affect NGOs, Venice 22-23 June 2018, available at $<$ https://www.osce.org/odihr/385932?download=true> accessed 1 June 2020.

10 HCC press release on the constitutionality of the acts on administrative courts available at $\leq$ https:// hunconcourt.hu/announcement/the-act-on-administrative-courts-is-in-line-with-the-fundamental-law/> accessed 1 June 2020.

Open Access. This is an open-access article distributed under the terms of the Creative Commons Attribution 4.0 International License (https://creativecommons.org/licenses/by/4.0/), which permits unrestricted use, distribution, and reproduction in any medium, provided the original author and source are credited, a link to the CC License is provided, and changes - if any - are indicated. (SID_1) 